\title{
Regional and Population-scale Influences on Genetic Diversity Partitioning within Costa Rican Populations of the Pioneer Tree Vochysia ferruginea Mart.
}

\author{
By S. Cavers ${ }^{1), 6)}$, C. Navarro ${ }^{2)}$, P. Hopkins ${ }^{3), 1)}$, R. A. Ennos ${ }^{4)}$ and A. J. Lowe ${ }^{1), 5)}$
}

(Received $31^{\text {th }}$ May 2005)

\begin{abstract}
The neotropical pioneer species Vochysia ferruginea is locally important for timber and is being increasingly exploited. The sustainable utilisation of this species would benefit from an understanding of the level and partitioning of genetic diversity within remnant and secondary regrowth populations. We used data from total genome (amplified fragment length polymorphism, AFLP) and chloroplast genome markers to assay diversity levels within seven Costa Rican populations. Significant chloroplast differentiation between Atlantic and Pacific watersheds was observed, suggesting divergent historical origins for these populations. Contemporary gene flow, though extensive, is geographically constrained and a clear pattern of isolation by distance was detectable when an inter-population distance representing gene flow around the central Costa Rican mountain range was used. Overall population differentiation was low $\left(F_{S T}=0.15\right)$ and within-population diversity high, though variable $(H s=0.16-0.32)$, which fits with the overall pattern of population genetic structure expected for a widespread, outcrossed tropical tree. However genetic diversity was significantly lower and differentiation higher for recently colonised and disturbed populations compared to that at more established sites. Such a pattern seems indicative of a pioneer species undergoing repeated cycles of colonisation and succession.
\end{abstract}

Key words: AFLP, chloroplast DNA, genetic diversity, gene flow, succession.

\section{Introduction}

In many parts of the neotropics, primary forest is being cleared or degraded (FAO, 2001). Central America faces a particularly severe problem, with some countries estimated to have little or no undisturbed forest remaining outside protected areas (KLEINN et al., 2002; SolORZANO et al., 1991; CALVO, 1990). One major consequence of this trend is that the area covered by sec-

1) Centre for Ecology and Hydrology-Edinburgh, Bush Estate, Penicuik, Midlothian EH26 0QB, Scotland, UK.

2) Centro Agrónomico Tropical de Investigación y Enseñanza, Cartago, Turrialba 7170, Costa Rica.

3) Royal Botanic Gardens, Edinburgh, 20A Inverleith Row, Edinburgh, EH3 5LR.

4) Institute of Cell, Animal and Population Biology, School of Biology, University of Edinburgh, Ashworth Laboratories, West Mains Road, Edinburgh EH9 3JT.

5) School of Integrative Biology, University of Queensland, St. Lucia, Brisbane, Queensland 4072, Australia.

$\left.{ }^{6}\right)$ To whom correspondence should be addressed. Centre for Ecology and Hydrology, Edinburgh, Bush Estate, Penicuik, Midlothian EH26 0QB, Scotland, UK.

Tel. 0131445 4343, Fax 0131445 3943, Email: scav@ceh.ac.uk ondary forest growth is expanding and assuming increasing importance as a resource (HERRERA et al., 1999; HAGGAR et al., 1997; FINEGAN, 1992; WADSWORTH, 1987). As a result, there is heightened interest in exploiting secondary forest productivity (KAMMESHEIDT, 2002; FinEGAN, 1992), as well as the use of secondary growth and plantation as a means of preserving and restoring habitat diversity (HAGGAR et al., 1997; LUGO, 1997). Secondary forest species are characteristically abundant and fast-growing (HARTSHORN, 1983), and the majority of late pioneer species are economically utilisable (FInEGan, 1992). To promote sustainability of exploitation, as secondary forest assumes greater economic and biological importance, it is important to understand how genetic variation is structured, moves and is maintained for key pioneer/early successional species.

Genetic structure in secondary forest species is likely to be strongly influenced by characteristic pioneer processes of rapid colonisation. Bottlenecks can be expected to occur, as population size increases quickly from a small founding source, and local factors (e.g. distribution and number of source trees, patterns of gene flow) and successional stage influences population diversity. However, theoretical studies have shown that colonisation/extinction cycles have complex consequences for genetic structure (MCCAULEY, 1991; Alvarez-Buylla and Garay, 1994). For example, it has been hypothesised that such cycles can result in strong population substructuring (WRIGHT, 1940) or can cause reduced interpopulation differentiation, due to raised gene flow rates (SlATKIN, 1987; MCCAUlEY, 1991). Genetic structure in such species may be further complicated by the imprint of long term historical processes, particularly in regions where strong topographic or environmental boundaries exist. Therefore to gain an insight into these processes, genetic data highlighting both contemporary and historical patterns of population structure are required.

Costa Rica has been significantly affected by deforestation during the past 50 years (deforestation rate averaged $3.9 \%$ per year from 1950-1984, KLEINN et al., 2002) and secondary forest forms a substantial resource. Costa Rica is located in the Mesoamerican biodiversity hotspot (MYERs et al., 2000) since it combines biotic influences from both North and South American colonisation and has a dramatic topography producing a wide range of environmental regimes over a small spatial scale. In particular, the steep mountain ranges between the Pacific and Atlantic slopes of the country represent a substantial physical barrier. Previous phylogeographic 


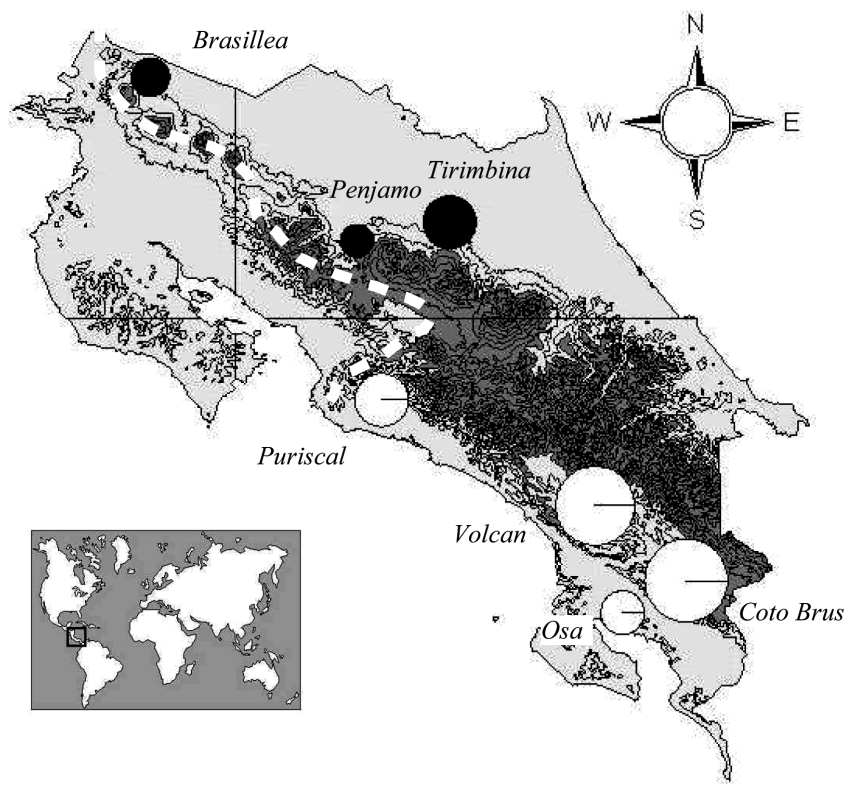

Figure 1. - Relief map of Costa Rica showing distribution of chloroplast DNA haplotypes in V. ferruginea. Inset shows location of Costa Rica on a global scale. The distribution of the two cpDNA haplotypes identified is shown, black = Atlantic haplotype, white = Pacific haplotype. Size of circle indicates sample size of population (numbers were Penjamo, $\mathrm{N}=9$; Tirimbina, $\mathrm{N}=13$; Coto Brus, $\mathrm{N}=20$; Volcan, $\mathrm{N}=19$; Brasillea, $\mathrm{N}=10$; Osa $\mathrm{N}=11$; Puriscal, $\mathrm{N}=19$ ). Dashed white line indicates limit of $V$. ferruginea distribution in Costa Rica - the species is not found in the dry northwest of the country. Areas above the $1000 \mathrm{~m}$ contour line (upper altitudinal limit of the species) are shaded dark grey.

studies (CAVERS et al., 2003; DiCK et al., 2003; NovicK et al., 2003) have identified zones of strong intraspecific differentiation, most likely the footprint of past colonisation events related to the rise of the Isthmus of Panama, further emphasising the importance of the region for biodiversity conservation.

FinEGAN (1992) has identified the secondary pioneer, Vochysia ferruginea, as having strong potential as a commercially viable crop for degraded sites in the neotropics. It is tolerant of low nutrient levels and high concentrations of toxic elements such as Aluminium (Al) and Iron ( $\mathrm{Fe}$ ), and has utility as a timber tree (for boxes, furniture, panels, veneer; FLORES, 1993). Vochysia ferruginea is a widespread, long-lived (CROAT, 1978) dominant of secondary forest below $1000 \mathrm{~m}$. It is found at low density as as a canopy tree in old-growth forests, usual- ly on slopes or less fertile soils (HERRERA and FinEGAN, 1997) and quickly colonises disturbed areas. In Costa Rica $V$. ferruginea is limited to the Atlantic lowlands and southern parts of the Pacific watershed, and does not occur in the dry northwest (Guanacaste). Flowers are hermaphrodite and the species has a reported mixed mating system (FloRES, 1993; BAWA et al., 1985). Pollination is primarily insect-mediated and seed are dispersed by gravity and wind (FLORES, 1993). V. ferruginea is highly resilient to disturbance (BOUCHER and MALONA, 1997; BOUCHER et al., 1994), and recovers well following extreme events, such as hurricane damage, fire or human activities, such as clearance.

To identify the major components of genetic structure and explore the dynamics of diversity within V. ferruginea populations, a combination of chloroplast (PCRRFLP) and total (AFLP) genomic markers are applied here to collections from across Costa Rica. The structure of cpDNA variation, which is often applied to infer historical colonisation patterns, is assessed for $V$. ferruginea in relation to topography and known species biology and history. Contemporary patterns of gene flow at a regional-scale are inferred using an isolation by distance test applied to pairwise population divergence estimates derived from AFLP data. The partitioning of variation identified by this combination of markers is discussed in relation to patterns of evolutionary divergence previously found in the region for other species. Finally the level and partitioning of AFLP diversity within and between populations are discussed in relation to V. ferruginea's life history and population successional stage.

\section{Methods}

Samples were collected from $140 \mathrm{~V}$. ferruginea individuals in 7 populations from throughout Costa Rica (Figure 1, Table 1). Populations were defined as groups of trees within a relatively coherent geographic area (i.e. in the same block of forest, uninterrupted by major geographical features or habitat changes), such that they were likely to be in reproductive contact. Individuals were sampled at least $100 \mathrm{~m}$ apart, to avoid sampling close relatives, and collected by taking leaf tissue, which was immediately dried on silica gel. Genomic DNA was extracted using a modified CTAB protocol (GILLIES et al., 1997). Twenty individuals were sampled per population however, due to amplification difficulties, final analysed population numbers were variable (Figure 1, Table 2).

Table 1. - Names and locations of populations used to determine levels and distribution of genetic diversity in $V$. ferruginea. Density scale is as follows: 1 -dense, approaching monospecific, 2 - large numbers in patchy distribution, 3 - large numbers in natural forest, 4 - disturbed, only remainder trees and forest fragments, 5 - sparse, approaching natural primary forest distribution.

\begin{tabular}{|c|c|c|c|c|c|c|c|}
\hline Population & $\begin{array}{l}\text { Lat. } \\
\left({ }^{\circ} \mathrm{N}\right)\end{array}$ & $\begin{array}{l}\text { Long. } \\
\left({ }^{\circ} \mathrm{W}\right)\end{array}$ & $\begin{array}{l}\text { Alt. } \\
\text { (m) }\end{array}$ & Adjacent landuse & Disturbance & Density & $\begin{array}{c}\text { Diameter }(\mathrm{cm}) \\
\text { mean }(\text { min-max })\end{array}$ \\
\hline Penjamo & $10^{\circ} 33^{\prime}$ & $84^{\circ} 48^{\prime}$ & 400 & Farm: sugarcane & Cleared $15-20$ ya, regenerating & 1 & $33.2(18-60)$ \\
\hline Tirimbina & $10^{\circ} 40^{\prime}$ & $84^{\circ} 10^{\prime}$ & 200 & Farm & Secondary, disturbed & 4 & $47.3(12-83)$ \\
\hline Coto Brus & $8^{\circ} 88^{\prime}$ & $83^{\circ} 08^{\prime}$ & 250 & Farm & Logged / disturbed & 4 & $38.0(15-68)$ \\
\hline Volcan & $9^{\circ} 20^{\prime}$ & $83^{\circ} 45^{\prime}$ & 400 & Farm: pineapple & Isolated forest fragment & 2 & $41.3(17-66)$ \\
\hline Brasillea & $11^{\circ} 03$ & $85^{\circ} 36^{\prime}$ & 300 & Crop farming & Secondary disturbed & 4 & $40.3(19-77)$ \\
\hline Osa & $8^{\circ} 75^{\prime}$ & $83^{\circ} 34^{\prime}$ & 100 & Forest & Selective extraction has occurred & 2 & $34.1(18-49)$ \\
\hline Puriscal & $9^{\circ} 66^{\prime}$ & $84^{\circ} 37^{\prime}$ & 330 & Forest & Secondary - some original trees & 4 & $31.5(10-54)$ \\
\hline
\end{tabular}


Table 2. - Levels of genetic diversity for seven populations of $V$. ferruginea from Costa Rica from AFLP data (represented by expected heterozygosity, $H$ ) with allele frequencies estimated using the approach of LYNCH and Milligan (1994). The data set consisted of 61 loci from four AFLP primer combinations. Standard errors on diversity values (calculated following LYNCH and MILLIGAN, 1994) given in brackets.

\begin{tabular}{lcccc}
\hline Population & $\begin{array}{c}\text { Sample } \\
\text { size }\end{array}$ & $\begin{array}{c}\text { No. of } \\
\text { polymorphic } \\
\text { loci }\end{array}$ & $\begin{array}{c}\text { \% of } \\
\text { polymorphic } \\
\text { loci }\end{array}$ & $H$ \\
\hline Penjamo & 20 & 40 & 65.6 & $0.19(0.02)$ \\
Tirimbina & 19 & 21 & 34.4 & $0.16(0.02)$ \\
Coto Brus & 6 & 47 & 77.0 & $0.32(0.02)$ \\
Volcan & 20 & 44 & 72.1 & $0.30(0.03)$ \\
Brasillea & 20 & 44 & 72.1 & $0.28(0.02)$ \\
Osa & 16 & 44 & 72.1 & $0.28(0.02)$ \\
Puriscal & 19 & 44 & 72.1 & $0.28(0.03)$ \\
Total & $\mathbf{1 2 0}$ & $\mathbf{4 3}$ & $\mathbf{7 0 . 5}$ & $\mathbf{0 . 2 6}(0.02)$ \\
\hline
\end{tabular}

Screening for variation in the chloroplast DNA (cpDNA) used the universal primers described in Demesure et al. (1995), Dumolin-LAPEGue et al. (1997b) and Hamilton (1999). The PCR protocol was as described in DEMESURE et al. (1995). PCR fragments were digested using combinations of several restriction enzymes (4-base: HinfI, MspI, AluI, HaeIII; 6-base: EcoRV, PstI, HindIII) and RFLP fingerprints were visualised on $8 \%$ non-denaturing acrylamide gel (Hoeffer SE600). Once polymorphic markers had been detected, the whole collection was characterised for cpDNA haplotype using these markers. The data set was analysed for within-population $\left(\mathrm{H}_{\mathrm{S}}\right)$ and total $\left(\mathrm{H}_{\mathrm{T}}\right)$ diversity and for the level of population subdivision $\left(\mathrm{G}_{\mathrm{ST}}\right)$ using the program HAPLONST (Pons and PETIT, 1995).

The AFLP protocol was as described in Vos et al. (1995), using four $E c o+2 / M s e+4$ selective primer combinations: E-CG / M-TACT, E-GC / M-CTGC, E-GC / MCACA, E-CC / M-CACA. AFLP fingerprints were visualised on a LICOR-IR sequencer, with only the EcoRI selective primer labelled with an IR fluorescent tag (IRD 700 / 800, MWG Biotech). Reactions were denatured for 5 mins. at $95^{\circ} \mathrm{C}$ prior to loading, then $1 \mu \mathrm{l}$ of reaction was loaded onto a $6 \%$ denaturing polyacrylamide gel (LongRanger $^{\mathrm{TM}}$ Gel solution, BMA) prepared according to manufacturers instructions and including treatment with $\mathrm{AG}^{\circledR} 501-\mathrm{X} 8$ resin (Biorad), filtration and degassing prior to polymerisation. Gels were scored for presence / absence of bands and a binary matrix was prepared. Population diversity level and structure were analysed following the approach of LYNCH and MILLIGAN (1994) with removal of all loci with band frequencies greater than 0.95 or less than 0.05 . Allele frequencies, estimated by a Bayesian method with non-uniform prior distribution, were used to calculate expected heterozygosities within populations $\left(H_{S}\right)$ and for the dataset as a whole $\left(H_{T}\right)$ using the program AFLP-SURV (VEKEMANs et al., 2002). Standard errors were calculated for all diversity estimates following the approach of LYNCH and MILLIGAN (1994), i.e., the square root of the variance of the diversity estimate. $F_{S T}$ was estimated between all populations and between combinations of grouped populations (e.g. according to cpDNA haplotype). All statistics quoted are unbiased estimates. Significance levels for the fixation indices were obtained by bootstrapping with 1000 permutations.

The relationship between population differentiation and geographic distance (isolation by distance) was investigated using a Mantel test (using the program zt, BONNET and VAN DE PEER, 2002). A matrix of pairwise $F_{S T}$ values between all populations was prepared. This was tested for correlation with a matrix of pairwise geographic distances between all populations. A significance level for the test statistic, $r$, was generated by 10000 random permutations of the $F_{S T}$ matrix. Two geographic distance matrices were prepared: one using Euclidean distances, and the other a "linearised" version of the real distances (e.g. SorK et al., 1999; KUDOH and WHIGHAM, 1997), representing the gene flow distance between populations through suitable habitat - i.e. around (north to south, below 1000m) rather than over (east to west) the central mountain ranges of Costa Rica. Using this approach, populations from the Atlantic and Pacific watersheds are only 'connected' via the mountain passes which dip below $1000 \mathrm{~m}$ in the north of the country (Figure 1).

\section{Results}

Two cpDNA primer / enzyme combinations were found to be polymorphic in $V$. ferruginea: both identified small insertion / deletion mutations (Table 4). The mutations segregated together and characterise two haplotypes (Table 4). In all cases, populations were fixed for a single haplotype $\left(\mathrm{G}_{\mathrm{ST}}=1.00\right)$. One haplotype was found exclusively to the east of the mountain ranges (Atlantic) and the other exclusively to the west (Pacific, Figure 1).

AFLP analysis obtained 61 loci from four primer combinations. Based on these markers, population-level diversity was found to vary considerably (Table 2), in particular the estimates for Penjamo and Tirimbina were significantly lower (at 95\% confidence level) than those for the other populations, $H_{S}=0.19(\mathrm{SE}=0.02)$ and $0.16(0.02)$, respectively. The remaining populations had diversity estimates in the range $H_{S}=0.28-0.32$. The mean within-population diversity was $H_{W}=0.26(0.02)$ 
Table 3. - Pairwise $F_{S T}$ estimates between all populations. The data set consisted of 61 loci from four AFLP primer combinations.

\begin{tabular}{llllllll}
\hline & Penjamo & Tirimbina & $\begin{array}{l}\text { Coto } \\
\text { Brus }\end{array}$ & Volcan & Brasillea & Osa & Puriscal \\
\hline Penjamo & 0 & & & & & & \\
Tirimbina & 0.21 & 0 & & & & & \\
Coto Brus & 0.19 & 0.23 & 0 & & & & \\
Volcan & 0.28 & 0.35 & 0.05 & 0 & & & \\
Brasillea & 0.16 & 0.26 & 0.05 & 0.06 & 0 & & \\
Osa & 0.23 & 0.31 & 0.04 & 0.04 & 0.02 & 0 & \\
Puriscal & 0.20 & 0.25 & 0.04 & 0.07 & 0.04 & 0.01 & 0 \\
\hline
\end{tabular}

and that of the collection as a whole was $H_{T}=0.30$ (0.02). To examine hierarchical partitioning of variation, populations were assigned to a Pacific or Atlantic group (according to their geographic location relative to the central mountain ranges) and fixation indices were estimated. There was a moderately high level of differentiation between all populations (ungrouped, $F_{S T}=0.15$ ) and between populations grouped according to chloroplast haplotype, $\left(F_{S T}=0.09\right)$. However, including the lowdiversity populations (Penjamo and Tirimbina) resulted in the highest values for estimates of $F_{S T}$. These two populations make a large contribution to the overall (ungrouped) differentiation estimate (Table 3); and the $F_{S T}$ estimate for the five high-diversity populations alone was low $\left(F_{S T}=0.04\right)$. All $F_{S T}$ values were significant.

It was possible to identify an isolation by distance effect when local topography was taken into account. Using Euclidean distance between populations, no significant relationship was identified between genetic $\left(F_{S T}\right)$ and geographic distance $(\mathrm{r}=0.10 ; p=0.48)$. However, the relationship was significant and positive when the distance matrix used was transformed by linearisation to represent expected gene flow pathways $(\mathrm{r}=0.59$; $p<0.01)$.

\section{Discussion}

Costa Rican populations of $V$. ferruginea show strong spatial genetic structuring at a regional scale. In particular, Atlantic and Pacific watershed samples were completely differentiated for cpDNA markers $\left(\mathrm{G}_{\mathrm{ST}}=1.00\right)$. At the same time, significant isolation by distance was detected when the inter-population spatial distance took account of the central Costa Rican mountain range (i.e. represented a gene flow distance). Clearly, differentia-

Table 4. - Description of the two cpDNA haplotypes identified. Numbers 1 and 2 indicate character state of fragment present, in decreasing order of size (bp). For distribution of cpDNA haplotypes see Figure 1. Full details of primers / enzymes available from authors.

\begin{tabular}{lll}
\hline & \multicolumn{2}{l}{ Polymorphic fragments (bp) } \\
\cline { 2 - 3 } & VF1 & VF2 \\
& $1-300$ & $1-750$ \\
& $2-290$ & $2-730$ \\
Haplotypes & indel & indel \\
\hline Pacific & 1 & 1 \\
Atlantic & 2 & 2 \\
\hline
\end{tabular}

tion is being maintained by landscape features and furthermore, it seems likely that, given the fixation of cpDNA haplotypes in these populations, the divergence has a historical origin. One explanation for such a combination of patterns is that total gene flow (probably primarily mediated by pollen) has recently been extensive and geographically constrained, but that Atlantic and Pacific populations may have been derived from historically separated sources. In studies of European Oaks (PETiT et al., 1997, 2002), cpDNA structure laid down during colonisation was temporally robust due to the low probability of immigration of foreign seed once a population was established (DAVIES et al., 2004). Meanwhile, the high relative vagility of pollen (approx migration ratio of 1:250 compared to seed) meant that, for nuclear markers, the imprint of colonisation was erased much more rapidly and a graded pattern of isolation by distance was evident (KREMER and ZANETTO, 1997; KREMER et al., 2002). A similar process may be operating within $V$. ferruginea.

Biogeographic studies indicate that many species have migrated northward from South America into Central America following the formation of the Panamanian Isthmus (ca 3 MYA; RAVEN and AxELROD, 1974; BuRNHAM and GRAHAM, 1999). In a number of recent, independent studies, strong phylogeographic structure has been identified in the region of the Panamanian Isthmus (e.g. Cedrela odorata, CAVERs et al., 2003; pseudoscorpions, ZEH et al. 2003; freshwater fish, BERMINGHAM and MARTIN 1998). For $V$. ferruginea, the differentiation within Costa Rica may represent an imprint of similar past colonisation processes and potentially a zone of secondary contact between differentiated sources. However, based on the current data it is not possible to identify patterns of migration or potential source populations in $V$. ferruginea and a wider phylogeographic survey would be of value.

Long-lived, outcrossed tropical tree species are predicted to exhibit high levels of within-population diversity and low population differentiation (HAMRICK and GODT, 1989, 1996). In addition, species with extensive pollen and seed dispersal maintain greater genetic connectivity between populations. For example, the outcrossing tropical tree species Swietenia macrophylla (GILLIES et al., 1999, RAPDs), Ilex paraguarensis (GAUER and CAVAlli-Molina, 2000, RAPDs) and Calycophyllum spruceanum (RUssell et al., 1999, AFLPs) have withinpopulation diversity levels of $0.36,0.16,0.28$ and population differentiation components of $0.12,0.15$ and 0.09 , 
respectively. For $V$. ferruginea, overall estimates of population-level diversity $(H=0.16-0.32)$ and subdivision $\left(F_{S T}=0.15\right)$ are within this range. Therefore, in general, the scale of diversity and population differentiation in $V$. ferruginea fits predictions.

A wide range of within-population diversity levels was found $\left(H_{S}=0.16-0.32\right)$ suggesting local history may also be important to population structuring in $V$. ferruginea. Populations of pioneer species at early successional stages should exhibit low levels of diversity due to foundation bottlenecks. New site colonisation and associated bottlenecking is also likely to increase differentiation between populations, although with time (and subsequent gene flow) this should decrease. Hence much higher levels of diversity within, and lower differentiation between, more established populations are expected. There is some support for these expectations for V. ferruginea. For example, populations Penjamo and Tirimbina maintain significantly lower levels of diversity and exhibited the highest differentiation estimates relative to all other populations (Table 2). Penjamo is known to have been clear-felled in the recent past (approximately 30 years ago, Table 1) and has regenerated naturally from neighbouring forest (FINEGAN and Delgado, 2000). The stand is dense, monospecific and even-aged and detailed spatial analysis indicates that it probably represents the progeny of a small number of mature trees (Lowe et al., in prep). The history of the population sampled at Tirimbina is not as well known as that at Penjamo, but it is on farmland with recently cleared and regenerated patches. Although this population is much less dense than Penjamo, and the regeneration pattern is not as clear, it is likely that all trees have established subsequent to land clearance. In contrast, the five high-diversity populations have lower density and generally have a more diverse age structure (from analysis of diameter and height measurements; data not presented). Genetic and historical data therefore suggest the occurrence of a population bottleneck at Penjamo and probably also Tirimbina. The clear evidence of a genetic bottleneck at Penjamo, caused by site clearance and recolonisation, demonstrates the substantial effect that pioneer life history can have on diversity of individual populations. However, although the link between colonisation and diversity is strong for the population at Penjamo (FINEGAN and Delgado, 2000), we cannot demonstrate a general link between diversity level and successional status. Our principal conclusion is therefore that within-population diversity is highly variable in $V$. ferruginea and that the low levels of differentiation match those observed in other studies of early to mid-successional species (e.g. $F_{S T}=0.03, C$. obtusifolia, Alvarez-Buylla and Garay, 1994; $F_{S T}=0.12$, C. alliodora, CHASE et al., 1995).

An extension of these results is that the maintenance of nearby, established 'source' populations, which are likely to exhibit higher diversity, will be important for landscape re-colonisation and genetic resource conservation. To enable long-term sustainable management of $V$. ferruginea, it will also be important to determine in detail the mechanisms by which diversity is maintained in the species. By identifying these pathways, diversity 'reserves' can be pinpointed, the mechanism by which diversity flows from mature to pioneer populations can be revealed and, by incorporating this data into management strategies, the genetic resources of this species can be maintained.

A number of new areas for further work have been identified by this study. Additional sampling of paired populations of established and regenerated stands from locations across the range of the species would help dissociate the influence of successional stage from gene flow on the magnitude of differentiation between populations. Also, it will be important, for management strategy, to examine actual pollen and seed dispersal distances and their impact on gene flow between neighbouring populations, particularly from established to recently colonised sites. To allow development of specific recommendations for forestry practice, the population level dynamics of regeneration and the breeding system should be examined in more detail, using nuclear codominant markers e.g. microsatellites (LowE et al., 2002). Finally, a wide ranging phylogeographic survey and seed dispersal / establishment studies (particularly close to the cpDNA disjunction) are required to explore the origin and significance of the cpDNA disjunction in the evolutionary history of $V$. ferruginea.

\section{Acknowledgements}

The work in this paper was conducted as part of the EU project "Assessment of levels and dynamics of intra-specific genetic diversity of tropical trees" (contract \# ERBIC18CT970149 http://www.nbu.ac.uk/inco, coordinated by A. J. Lowe) and contributed to S. CAVERS' Ph.D. thesis, which was part funded by NERC and supported by the Centre for Ecology and Hydrology, Edinburgh. Thanks to MARVin HeRnandez and Lionel Coto for assistance in obtaining samples. The authors would also like to thank JULIA WILSON (CEH) for constructive comments.

\section{References}

Alvarez-Buylla, E. R. and A. A. Garay (1994): Population Genetic-Structure of Cecropia obtusifolia, a tropical pioneer tree species. Evolution 48: 437-453.

Bawa, K. S., S. H. Bullock, D. R. Perry, R. E. Coville and M. H. Grayum (1985): Reproductive biology of tropical lowland rain forest trees. II. Pollination systems. American Journal of Botany 72: 346-356.

Bermingham, E. and P. A. MARTin (1998): Comparative mtDNA phylogeography of neotropical freshwater fishes: testing shared history to infer the evolutionary landscape of lower Central America. Molecular Ecology 7: $499-517$.

BonNET, E. and Y. vAN DE PEER (2002): zt: a software tool for simple and partial Mantel tests. Distributed by the author. VIB, Ghent University, K. L. Ledeganckstraat 35, B-9000, Ghent, Belgium.

Boucher, D. H., J. H. Vandermeer, M. A. Mallona, N. ZAmora and I. Perfecto (1994): Resistance and resilience in a directly regenerating rainforest: Nicaraguan trees of the Vochysiaceae after Hurricane Joan. Forest Ecology and Management 68: 127-136.

Boucher, D. H. and M. A. MALONA (1997): Recovery of the rainforest tree Vochysia ferruginea over 5 years following Hurricane Joan in Nicaragua: a preliminary popula- 
tion projection matrix. Forest Ecology and Management 91: 195-204.

Burnham, R. J. and A. Graham (1999): The history of neotropical vegetation: new developments and status. Annals of the Missouri Botanical Garden 86: 546-589.

Calvo, J. C. (1990): The Costa Rican National Conservation Strategy for Sustainable Development: exploring the possibilities. Environmental Conservation 17: 355-358.

CAVERS, S., C. NAvARro and A. J. Lowe (2003): Chloroplast DNA phylogeography reveals colonisation history of a Neotropical tree, Cedrela odorata L., in Mesoamerica. Molecular Ecology 12: 1451-1460.

Chase, M. R., D. H. Boshier and K. S. Bawa (1995): Population genetics of Cordia alliodora (Boraginaceae), a neotropical tree, 1 . Genetic variation in natural populations. American Journal of Botany 82: 468-475.

Croat, T. B. (1978): Flora of Barro Colorado Island., Stanford University Press: Palo Alto.

DAvies, S., A. White and A. J. Lowe (2004): An investigation into effects of long-distance seed dispersal on organelle population genetic structure and colonization rate: a model analysis. Heredity 93: 566-576.

Demesure, B., N. Sodzi and R. J. Petit (1995): A set of universal primers for amplification of polymorphic noncoding regions of mitochondrial and chloroplast DNA in plants. Molecular Ecology 4: 129-131.

Dick, C.W., K. AbDul-Salim and E. Bermingham (2003): Molecular systematic analysis reveals cryptic tertiary diversification of a widespread tropical rain forest tree. American Naturalist 162: 691-703.

Dumolin-Lapegue, S., M.-H. Pemonge and R. J. Petit (1997): An enlarged set of consensus primers for the study of organelle DNA in plants. Molecular Ecology 6: 393-397.

FAO (2001): The State of the Worlds Forests, Food and Agriculture Organisation, FAO, Rome. pp151.

FINEGAN B. (1992): The management potential of neotropical secondary lowland rainforest. For. Ecol. Mgmt. 47: 295-321.

Finegan B. and D. Delgado (2000): Structural and floristic heterogeneity in a 30-year-old Costa Rican rain forest restored, on pasture through natural secondary succession. Restoration Ecology 8: 380-393.

FloRes, E. M. (1993): Vochysia ferruginea (Mayo colorado, Red Yemeri). Arboles y Semillas del Neotropico 2: 29-52.

Gauer, L. and S. Cavalli-Molina (2000): Genetic variation in natural populations of mate (Ilex paraguarensis A. St.-Hil., Aquifoliaceae) using RAPD markers. Heredity 84: $647-656$.

Gillies, A. C. M., J. P. Cornelius, A. C. Newton, C. NAVARro, M. HeRnANDEZ and J. Wilson (1997): Genetic variation in Costa Rican populations of the tropical timber species Cedrela odorata L., assessed using RAPDs. Molecular Ecology 6: 1133-1145.

Gillies, A. C. M., C. Navarro, A. J. Lowe, A. C. Newton, M. Hernandez, J. Wilson and J. P. Cornelius (1999): Genetic diversity in Mesoamerican populations of mahogany (Swietenia macrophylla), assessed using RAPDs. Heredity 83: 722-732.

HagGar, J., K. Wightman and R. Fisher (1997): The potential of plantations to foster woody regeneration within a deforested landscape in lowland Costa Rica. Forest Ecology and Management 99: 55-64.

HAMilton, M. B. (1999): Four primer pairs for the amplification of chloroplast intergenic regions with intraspecific variation. Molecular Ecology 8: 521-522.
HAMrICK, J. L. and M. J. W. GoDT (1989): Allozyme diversity in plant species. In: (Brown, A. H. D., CleGG, M. T., KAHLER, A. L. and WeIR, B. S. ed.) Plant population genetics, breeding and genetic resources., Sinauer Associates Inc.: Sunderland, MA., pp. 43-63.

HAMRICK, J. L. and M. J. W. GODT (1996): Effects of life history traits on genetic diversity in plant species. Philosophical Transactions of the Royal Society of London B. 351: 1291-1298.

HARTSHORN, G. S. (1983): Plants: Introduction. In: (JANZEN, D. H. ed.) Costa Rican Natural History, University of Chicago Press: Chicago, pp. 118-157.

HerRerA, B. and B. FinEgAN (1997): Substrate conditions, foliar nutrients and the distribution of two canopy tree species in a Costa Rican rainforest. Plant Soil 191: $259-267$.

Herrera, B., J. J. CAmpos, B. Finegan and A. Alvarado (1999): Factors affecting site productivity of a Costa Rican secondary rain forest in relation to Vochysia ferruginea, a commercially valuable canopy tree species. Forest Ecology and Management 118: 73-81.

KAmmeSheIDT, L. (2002): Perspectives on secondary forest management in tropical humid lowland America. Ambio 31: 243-250.

KudoH, H. and D. F. Whigham (1997): Microgeographic genetic structure and gene flow in Hibiscus moscheutos (Malvaceae) populations. American Journal of Botany 84: $1285-1293$.

Kleinn, C., L. Corrales and D. Morrales (2002): Forest area in Costa Rica: a comparative study of tropical forest cover estimates over time. Environmental Monitoring and Assessment 73: 17-40.

KREMER, A. and A. ZANETTO (1997): Geographical structure of gene diversity in Quercus petraea (Matt.) Liebl. II: multilocus patterns of variation. Heredity 78: $476-489$.

Kremer, A., J. Kleinschmit, A. Koenig, N. Cundall, J. D. Deans, A. J. Lowe, R. C. Munro, R. J. Petit and R. STEPHAN (2002): Is there a correlation between chloroplastic divergence and phenotypic or nuclear genetic divergence in European oaks? Forest Ecology and Management 156: 75-88.

Lowe, A. J., W. P. Goodall-Copestake, H. Caron, A. KREMER and S. DECROOCQ (2002): A set of polymorphic microsatellites for Vochysia ferruginea, a promising tree for land reclamation in the Neotropics. Molecular Ecology Notes 2: 153-155.

Lowe, A. J., S. Cavers, W. P. Goodall-Copestake and C. NAVARRO: In Prep. Fine-scale genetic structure within Costa Rican populations of Vochysia ferruginea Mart., at different colonisation stages.

Lugo, A. E. (1997): The apparent paradox of reestablishing species richness on degraded lands with tree monocultures. Forest Ecology and Management 99: 9-19.

LYNCH, M. and B. G. MilligAN (1994): Analysis of population genetic structure with RAPD markers. Molecular Ecology 3: 1-9.

McCauley, D. E. (1991): Genetic Consequences of LocalPopulation Extinction and Recolonization. Trends in Ecology \& Evolution 6: 5-8.

Myers, N., R. A. Mittermeier, C. G. Mittermeier, G. A. B. DA FonsecA and J. Kent (2000): Biodiversity hotspots for conservation priorities. Nature 403: 853-858.

Novick, R. R., C. W. Dick, M. R. Lemes, C. Navarro, A. CACCONE and E. Bermingham (2003): Genetic structure of Mesoamerican populations of Big-leaf mahogany (Swietenia macrophylla) inferred from microsatellite analysis. Molecular Ecology 12: 2885-2893. 
Petit, R. J., S. Brewer, S. Bordacs, K. Burg, R. CheddADi, E. CoArt, J. CotTrell, U. M. Csaikl, B. van Dam, J. D. Deans, S. Espinel, S. Fineschi, R. Finkeldey, I. Glaz, P. G. Goicoechea, J. S. Jensen, A. O. Konig, A. J. Lowe, S. F. Madsen, G. Matyas, R. C. Munro, F. Popescu, D. Slade, H. Tabbener, S. G. M. De Vries, B. Ziegenhagen, J. L. DE Beaulieu and A. Kremer (2002): Identification of refugia and post-glacial colonisation routes of European white oaks based on chloroplast DNA and fossil pollen evidence. Forest Ecology and Management 156: 49-74.

Petit, R. J., E. Pineau, B. Demesure, R. Bacilieri, A. Ducousso and A. KRemer (1997): Chloroplast DNA footprints of postglacial recolonization by oaks. Proceedings of the National Academy of Sciences USA 94: 9996-10001.

Pons, O. and R. J. Petit (1995): Estimation, variance and optimal sampling of gene diversity I. Haploid locus. Theoretical and Applied Genetics 90: 462-470. http://www.pierroton.inra.fr/genetics/labo/Software

RAVEN, P. H. and D. I. AxelRoD (1974): Angiosperm biogeography and past continental movements. Annals of the Missouri Botanical Garden 61: 539-673.

Russell, J. R., J. C. Weber, A. Booth, W. Powell, C. Sotelo-Montes and I. K. Dawson (1999): Genetic variation of Calycophyllum spruceanum in the Peruvian Amazon Basin, revealed by amplified fragment length polymorphism (AFLP) analysis. Molecular Ecology 8: 199-204.

Slatkin, M. (1987): Gene flow and the geographic structure of natural populations. Science 236: 787-792.
Solorzano, R., R. DE CAmino, R. Woodward, J. Tosi, V. Watson, A. VAsquez, C. Villalobos, J. Jimenez, R. REPETTO and W. CRUZ (1991): Accounts overdue: Natural resource depreciation in Costa Rica., World Resources Institute, Washington, DC.

Sork, V. L., J. D. NASON, D. R. CAMPBEll and J. F. FERNANDEZ (1999): Landscape approaches to historical and contemporary gene flow in plants. Trends in Ecology and Evolution 14: 219-224.

Vekemans, X., T. Beauwens, M. Lemaire and I. RoldanRUIZ (2002): Data from amplified fragment length polymorphism (AFLP) markers show indication of size homoplasy and of a relationship between degree of homoplasy and fragment size. Molecular Ecology 11: 139-151.

Vos, P., R. Hogers, M. Bleeker, M. Reijans, T. van De Lee, M. Hornes, A. Frijters, J. Pot, J. Peleman, M. KUIPER and M. ZABEAU (1995): AFLP: a new technique for DNA fingerprinting. Nucleic Acids Research. 23: $4407-4414$.

WADSWORTH, F. (1987): A time for secondary forest in Tropical America. In: FigueroA, J. C., WADSWOrth, F., BrANHAM, S. (Eds). Management of the forests of Tropical America: prospects and technologies. Institute of Tropical Forestry, USDA, Puerto Rico.

WRIGHT, S. (1940): Breeding structure of populations in relation to speciation. American Naturalist 74: $232-248$.

ZEH, J. A., D. W. ZeH and M. M. Bonilla (2003): Phylogeography of the harlequin beetle-riding pseudoscorpion and the rise of the Isthmus of Panama. Molecular Ecology 12: 2759-2769. 